\title{
Water accessibility impact on girl and women's participation in education and other development activities: the case of Wuchale and Jidda Woreda, Ethiopia
}

\author{
Getachew Demie*, Mulugeta Bekele and Berhanu Seyoum
}

\begin{abstract}
Background: Ethiopia has huge water resource potential. However, it contributed little to access to clean and safe drinking water supply and socio-economic development. The objective of this study was to assess water accessibility, its source and impact on females participation in education and other development activities at Wuchale and Jidda Woreda.

Methods: To achieve this, multiple stage sampling system was used and in the first stage two kebele were purposively selected from each Woreda based on water accessibility problems. Accordingly, a total of 197 households were selected systematically and data collection were made using questionnaire, interview, and focus group discussion. Data analysis were made using statistical package for social science (SPSS version 20.0) and Microsoft excel. Descriptive statistics, Chi-square, cross tabulation and regression analysis were used as analysis tools.

Results: The result of the study identified river (49.24\%) as major source of drinking water followed by unprotected spring, pond, hand dung boreholes and improved water supply point which account about 41.11, 7.11, 2.03 and $0.51 \%$ respectively. Access to safe drinking water is the major strange, as reiterated by $95 \%$ of the respondent. The finding also showed that the average per capita per day per person was about 14 litter which is less than WHO standard (20 litter) and GTP of Ethiopia (15 litter). An individual get water by going an average distance of $2.78 \pm 0.81 \mathrm{~km}$ from their residential area which was greater than the maximum distance standard ( $1 \mathrm{~km}$ ) set by WHO and UNICEF; and $1.5 \mathrm{~km}$ by Ministry of Water and Energy in universal access plan and gross and transformation document of Ethiopia. The study also showed that about $5.23 \pm 2.82 \mathrm{~h}$ per day were spent by girls and females for fetching water. Even after going long distance and spending a lots hours per day, the water they got lack sanitation and hygiene since they use in common with livestock and other living thing. Poor access to safe drinking water coupled with illiteracy (73.1\%) and water borne disease prevalence, greatly influenced the participation of girls and female in education, agricultural production and other development activities at study area.
\end{abstract}

Conclusions: Hence, urgent response with regard to providing access to safe drinking water should be given to the community by concerned body.

Keywords: Accessibility, Drinking water, Water borne diseases

\footnotetext{
*Correspondence: gech.demie1987@gmail.com

School of Natural Resources and Environmental Studies, Wondo Genet

College of Forestry and Natural Resources, Hawassa University, P.O.

Box 128, Shashemane, Ethiopia
}

\section{照) Springer}

(c) 2016 Demie et al. This article is distributed under the terms of the Creative Commons Attribution 4.0 International License (http://creativecommons.org/licenses/by/4.0/), which permits unrestricted use, distribution, and reproduction in any medium, provided you give appropriate credit to the original author(s) and the source, provide a link to the Creative Commons license, and indicate if changes were made. 


\section{Background}

Ethiopia was known as the 'water tower' of east Africa due to its huge water resource potential from lake, rivers, stream, reservoirs, small water bodies, flood plains and swamps. However, the country's water resources have contributed little to access to clean and safe water supply, socio-economic development, irrigation and hydropower (Kidanemaraim 2009). Most rivers that originate within the country flow across borders to neighboring countries, and are transboundary. Unevenness of the spatial and temporal distributions of water resource coupled with population growth and socioeconomic processes such as urbanization, industrialization and intensive agriculture have put an enormous pressure even on the available fresh water resources all over the world (Korca and Jusufi 2015). Furthermore, the increased water demands and degradation of its quality further intensified the water scarcity everywhere (OAS 1998).

Water play indispensible role in supporting economic development. However, its quantity and quality are determinant factors in influencing the function it provides for environment, economy and social needs (Garcia 1998; Young et al. 1994). The water problems are becoming increasingly more and more complex and interconnected with other development sectors like agriculture, energy, industry, and also with social, economic, environmental, health, educational, legal, and political factors at local and national levels and sometimes at regional and even international levels (Biswas 2004).

Water is essential for economic, environmental and social needs (Garcia 1998) and therefore the right to access to clean and fresh water is the basic right of human (Samra et al. 2011). However, most rural areas of the developing countries have no improved water supply and the impact was further aggravated as a result of high population growth (United Nations 2010; McCommon et al. 1998). The report of (World Health Orgnaization 2006) also pinpointed that about $84 \%$ of the world population was without access to an improved sources of drinking water in rural areas. In rural areas of poor countries, water supply is more of physical labor to obtain water or to lift water from a well and to carry it a considerable distance from the sources. Furthermore, it consumes a significant proportion of the time (Cherutich et al. 2015) .

Traditionally everywhere in developing world, women were given responsibility for collecting water (Luis et al. 2002) and they often spend substantial amounts of time in such activities (Amy and Jennifer 2012). The finding of Van de Walle and Gayatri (2010) also emphasized the point as women mired of collecting water and their offfarm labor force participation remains low in many poor countries. Understanding the situation, the government developed universal access to water program and strived for many years. Despite efforts were made, the problem of access to drinking water continues to plague the poor rural communities. One of such areas facing great challenge from inadequate access to drinking water were Wucale and Jidda Woreda. Furthermore, no studies were conducted regarding the situation in the study area. Hence, the overall aim of this study was to assess the impact of water accessibility on girls and women's participation in education and other development activities. The assumptions of study was that; gender difference and water accessibility doesn't have impact on girls and woman's education and participation in other development activities.

\section{Methods}

\section{Description of study area}

The study was conducted around north Shewa Wuchale and Jidda Woreda, Ethiopia. Wuchale and Jidda Woreda is located the central part of North Shewa Zone of Oromia between $9048^{\prime}$ North to $9048^{\prime}$ North latitude and $38045^{\prime}$ East and 39013' East longitude (Fig. 1). Wuchale and Jidda woreda are about 75 and $80 \mathrm{~km}$ distance from the Capital city of Addis Ababa respectively. According to Central statistics report of CSA (2007), they have a total population of 97,529 (among which 49,236 is male and 48,293 is female) and 53,658 (of whom 26,889 are male and 26,769 are female) respectively.

\section{Data collection methods}

A reconnaissance survey was done before actual collection of data to have an overview of the study area and to determine the sample size. To achieve the objectives of this particular study, both primary and secondary data was collected and used. A set of different techniques were applied to collect the data required to analyze the water accessibility and its impact on women's participation within study area. Focus group discussion, key informant interview, personal observation and household survey were used to collect primary data related to water accessibility, time elapsed for fetching, health related problems due to water, etc. Secondary data was collected from concerned offices; relevant literature and documents were also reviewed to provide theoretical framework. Prior to actual data collection, proper orientation was given to data collectors or enumerators to fully comprehend the objective of the survey and questions in the questionnaires.

\section{Sampling techniques}

To conduct data collection, multiple stage sampling techniques were used as depicted on study framework (Fig. 2). In the first stage, two kebele from each of the 


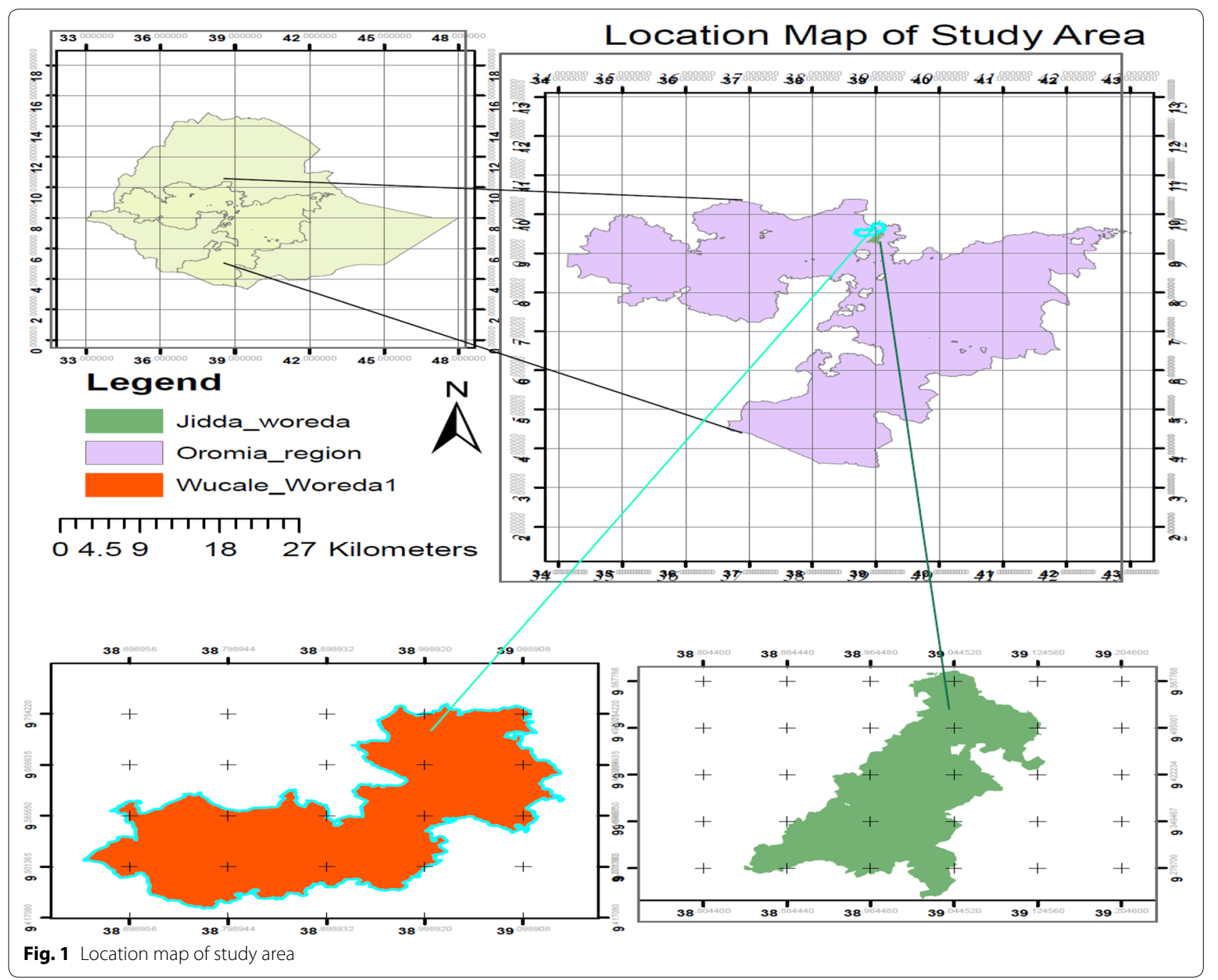

two Woreda (Siba Dega and Wanga Dega Nasiri from Jidda Woreda; Usmani and Gomoro Sabo from Wuchale Woreda) was purposively selected based on the problems of water accessibility. Following by the first stage, determination of household sample size were made and total of 197 household were selected using systematic sampling techniques (from Siba Dega about 46, 59 from Wagna Dega Nasiri, 48 from Usmani and 33 from Gomoro).

\section{Data analysis methods}

The data gathered through different tools were analyzed as per category of data (quantitative and qualitative). Data analysis were made using descriptive statistics (mean, percentage), Chi-square, cross tabulation and regression analysis by the help of statistical package for social science (SPSS) version 20.0 software and Microsoft excel. The results were presented in tables and graphs.

\section{Results and discussion}

Demographic characteristics of study area

Wuchale and Jidda woreda were characterized by high population density and different types of economic activity. Furthermore, the age structure also varied and the highest figure ( $39.59 \%$ ) is under $31-45$ age class followed by $16-30$ age class as shown on Fig. 3 below. This implies that most of the selected respondent are in productive age and hence able to participate in agricultural activities and education.

Among the total population selected for interview, about $73.03 \%$ were illiterate while the remaining 22.84 , 3.55 and $0.51 \%$ were those following their primary education, secondary and religious education (Fig. 4). In addition, as the result from data analysis indicated, there were variability among educational status of male and female respondent within study area. The percentage of females followed their education (primary or secondary) 


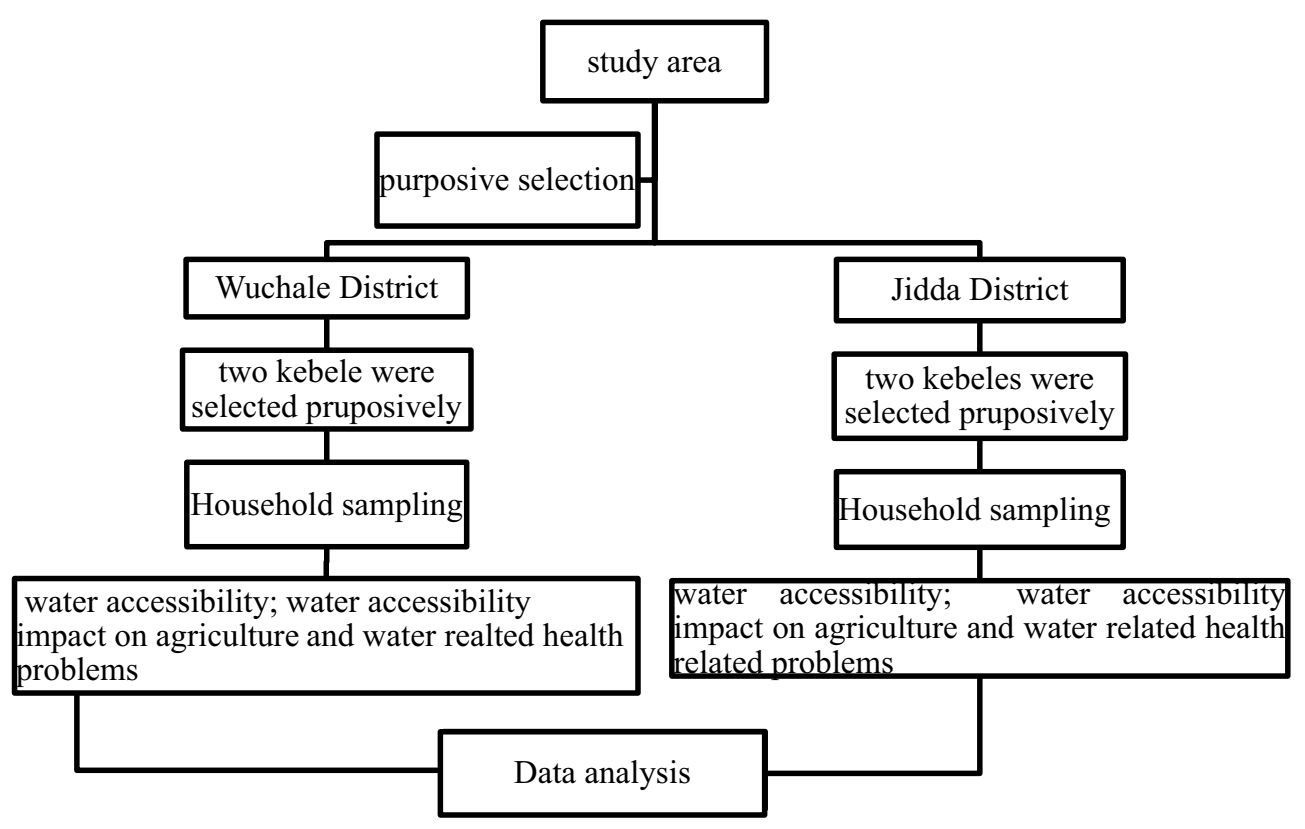

Fig. 2 Study framework

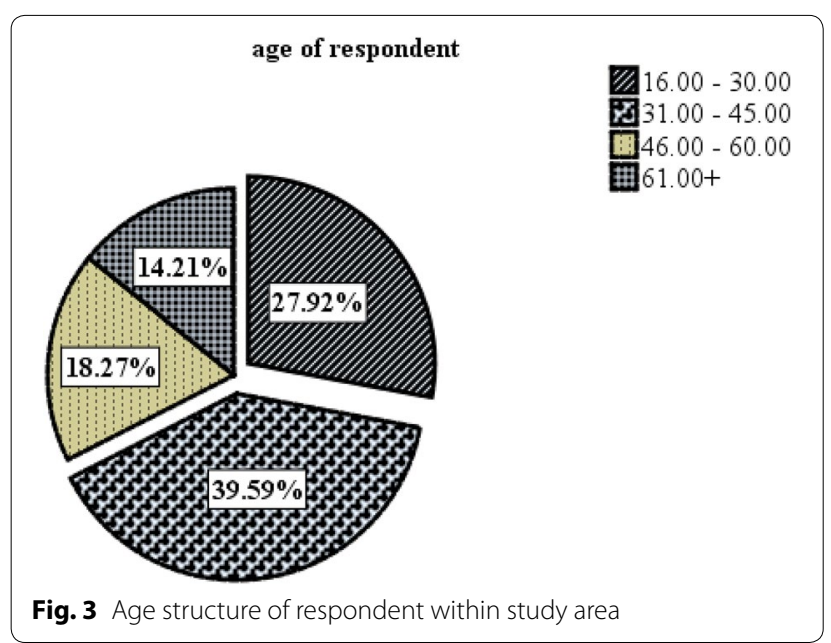

was about 32 (30.48 \%) while that of male was 21 $(22.83 \%)$. Among the total respondent from each sex category, $71(77.17 \%)$ male and 73 (69.52) females were illiterate. This implies that, most of the communities within study area were illiterate and doesn't have now how about water related health problems (water born disease) rather than thinking of getting any sort of water whether it is protected or unprotected river water, spring, etc. This was also had greater impact on water management aspect and participation of communities in different economic sector.
Animal husbandry was the main economic base followed by agricultural crop production in Wagna Dega Nasir and Siba Dega kebele of Jidda Woreda. However, in Usmani of Wucale Woreda, 50 \% agricultural crop production and the remaining $50 \%$ on animal husbandry while Gomoro Sabo is almost completely depend on livestock production. Based on the result obtained from the analysis of questionnaire survey, the average annual per-capita income of the study area was $455.76 \pm 228.72$ ETB. This is very small compared to the 315.99 USD annual GDP per capita report of World bank which was refreshed and reported on Saturday August 2015 (World bank 2015). The possible reason for this lower per capita within study area, as explained during focus group discussion and interview, was the occurrence of wheat rust and extension of dry period.

\section{Water accessibility and its impact \\ Water accessibility}

The major source of water supply within study area was river $(49.24 \%)$ followed by unprotected spring which account $41.11 \%$ (Table 1 ). The percentage coverage of improved water supply point is $.51 \%$ which is almost not available. The result of focus group discussion shows that about $88.5 \%$ of the respondent use the water for drinking, domestic use (mainly preparation of foods) rather that personal hygiene. They emphasized this point as there great strange for obtaining water for sustaining their live 


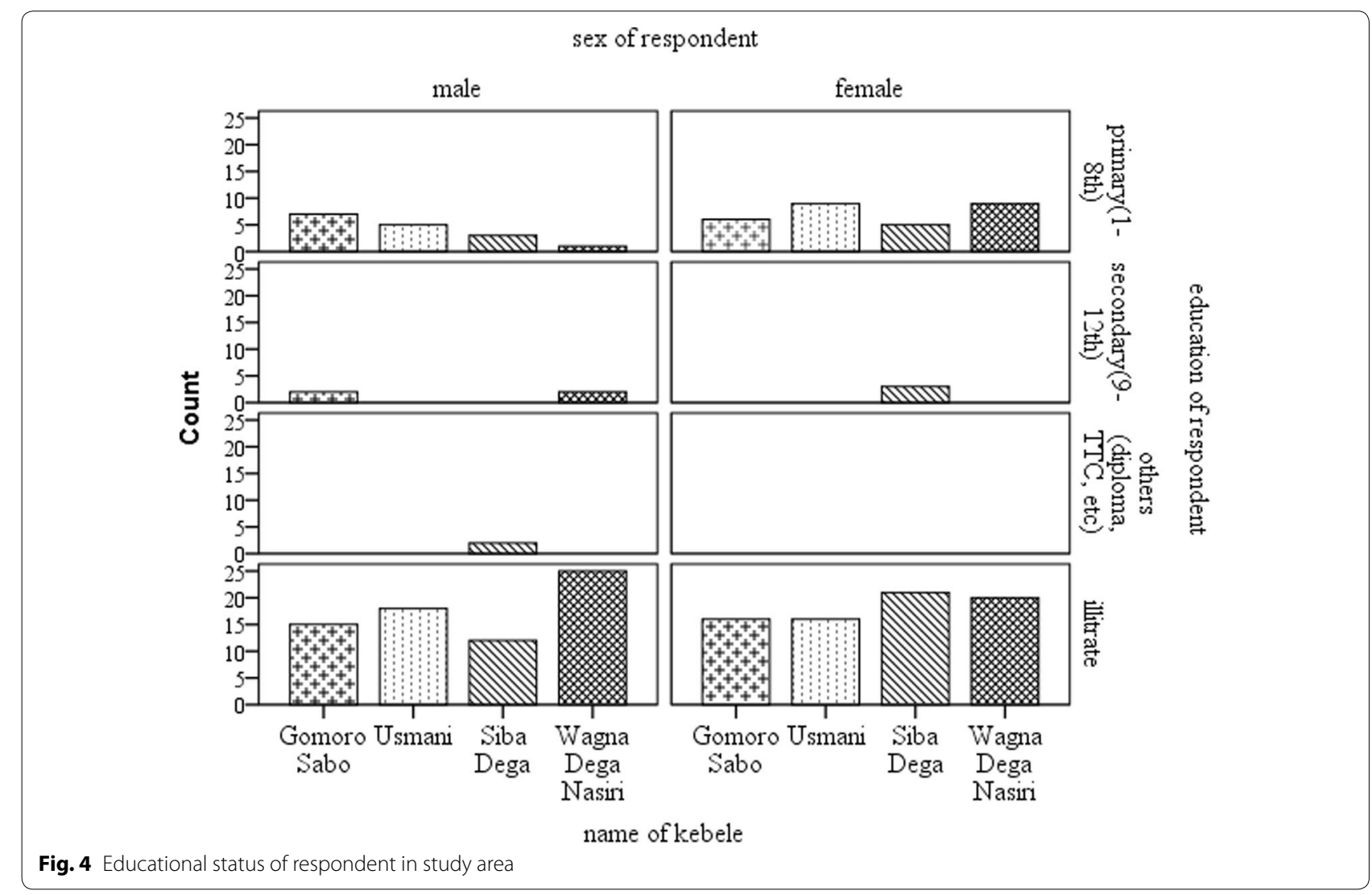

Table 1 The major source of water supply within study area

\begin{tabular}{lcccc}
\hline & Frequency & Percent (\%) & $\begin{array}{l}\text { Valid } \\
\text { percent }\end{array}$ & $\begin{array}{l}\text { Cumulative } \\
\text { (\%) }\end{array}$ \\
\hline Pond & 14 & 7.11 & 7.11 & 7.11 \\
River & 97 & 49.24 & 49.24 & 56.35 \\
$\begin{array}{l}\text { Improved water } \\
\text { supply point }\end{array}$ & 1 & 0.51 & 0.51 & 56.86 \\
$\begin{array}{l}\text { Unprotected } \\
\text { spring }\end{array}$ & 81 & 41.11 & 41.11 & 97.97 \\
$\begin{array}{l}\text { Hand dug bore } \\
\text { well }\end{array}$ & 4 & 2.03 & 2.03 & 100.0 \\
\begin{tabular}{c} 
Total \\
\hline
\end{tabular} & 197 & 100.0 & 100.0 & \\
\hline & & & & \\
\hline
\end{tabular}

instead of wishing joyful life as Debele Guta explained in his speech (Box 1). Nationally, the document prepared by Akeza and Faffere (2014) showed that about 50 \% population proportion doesn't get access to drinking water.

Access to drinking water is the human right (De Albuquerque 2012) and various international instruments implicitly confirmed the right to get clean water in the protocol on water and Health to the 1992 convention on the protection and use of Transboundary watercourse and international lakes which came into force in 2005.

\section{Box 1 .}

My name is 'Debele Guta'. I live here in Siba Dega for 60 years. Our kebele is mostly dependent on animal husbandry. The problem of access to water (weather it is water from river, spring, pond, etc.) within our kebele was greatly influencing our life and the life of our cattle. Our children, mainly girls and women, were un able to follow their education and participate in different day to day activities of our survival respectively. without water it is impossible to exist and work your economic activity efficiently. For instance, in this dynamic environment and frequently changing natural conditions, it is impossible to depend only on agricultural crop production. Hence in order to feed my family, based on the new technology advised by our development agent I was participating on fattening of cattle and sheep. However, due to lack of access to drinking water (even for cattle), I sold all of them and currently my family is in great strange. We need urgent response from our government with regard to water resource supply since our community are influenced by joint impact of climate change and water supply which in turn influence our livelihoods as well.

Indeed this is not the case, at Wuchale and Jidda Woreda where the access and availability of water was very strange as reiterated by $95 \%$ of the respondent. Based on the result of questionnaire survey, an individual person got water by going an average distance of $2.78 \pm 0.81 \mathrm{~km}$ from their residential area (Fig. 5) which is greater than the WHO and UNICEF (2000) maximum distance of 1 and $1.5 \mathrm{~km}$ standard set by Ministry of water and Energy 


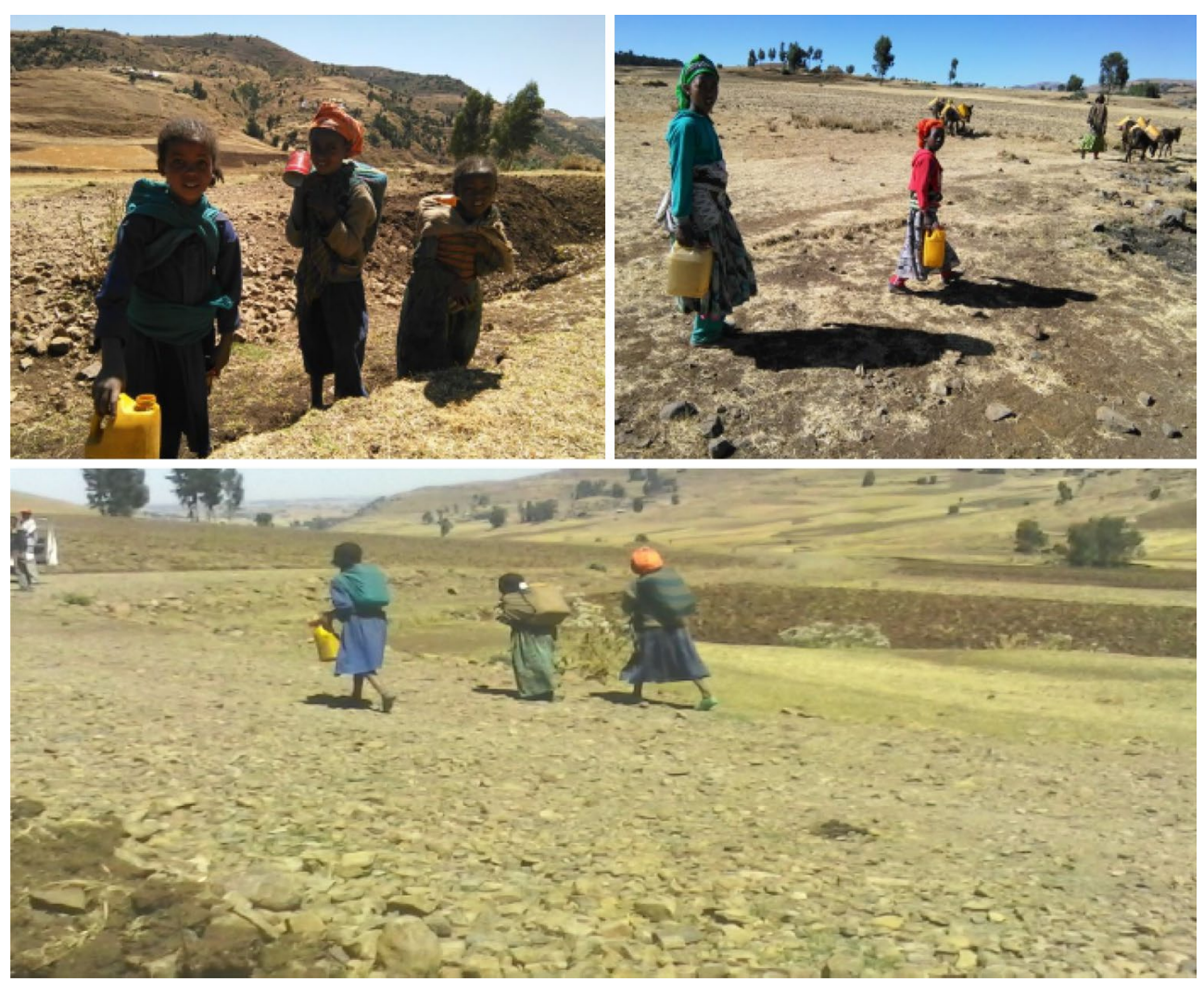

Fig. 5 Child girls going to their homes after fetching water on their back

(2009) in universal access plan and gross and transformation (GTP) document of Ethiopia. Even, after going long distance, they obtain water which has poor quality and aesthetic due to common use of the water source both for man being as well as other domestic animals (Fig. 6). This implies that it is impossible to achieve millennium development goals, target7C: sustainable access to safe drinking water and basic sanitation within study area. This was in line with the report of WHO and UNICEF (2006) which states that with current pace ensuring access to safe drinking water (which is extremely lower) in the sub-Saharan African including Ethiopia doesn't achieve the millennium development goal 7C. However, Ethiopia Millennium development goal report prepared by Ministry of Finance and Economic Development (Ministroy of Finance and Economic Development 2012) showed that the percentage of households with access to improved drinking water has increased from $25.3 \%$ in 2000 to $58.25 \%$ in 2011 which was almost very low achievement.

There was also time they unable to get these poor quality water due to seasonal variability mainly during extended dry period. They dig sediment in dried river plain for finding water for drinking (Fig. 7). The researchers field observation and interview with 197 sample household also proved they are spending most of their time looking for drinking water instead of taking part in different economic activities. This was in line with finding of Cherutich et al. (2015) and Luis et al. (2002) which states that low access to drinking water would affect the livelihoods of the society and it is extremely difficult to break the vicious circle of poverty (Kerstin and Cara 2012).

In almost all areas of Ethiopia, the responsibility of fetching water is given to female and the result of this study is also in line with the existing truth (Fig. 8). The result of data analysis show that the mean time spent per day for fetching water within study area was about $5.23 \pm 2.82 \mathrm{~h}$. This implies that $3-4 \mathrm{~h}$ per day of girls and women were spent for fetching drinking water and about $71.07 \%$ of the respondent collect water using their back while $8.63 \%$ use domestic animal mainly donkey. This problem was significantly higher than problems faced in other African countries. For instance, according to Roy et al. (2005), the average water collection times in 


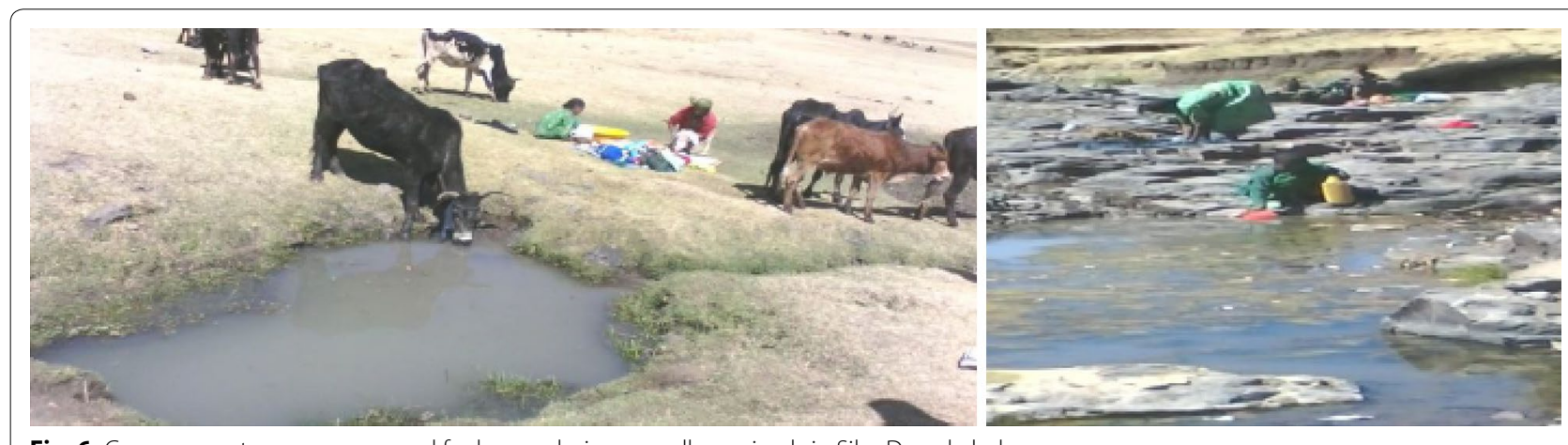

Fig. 6 Common water source are used for human being as well as animals in Siba Dega kebele

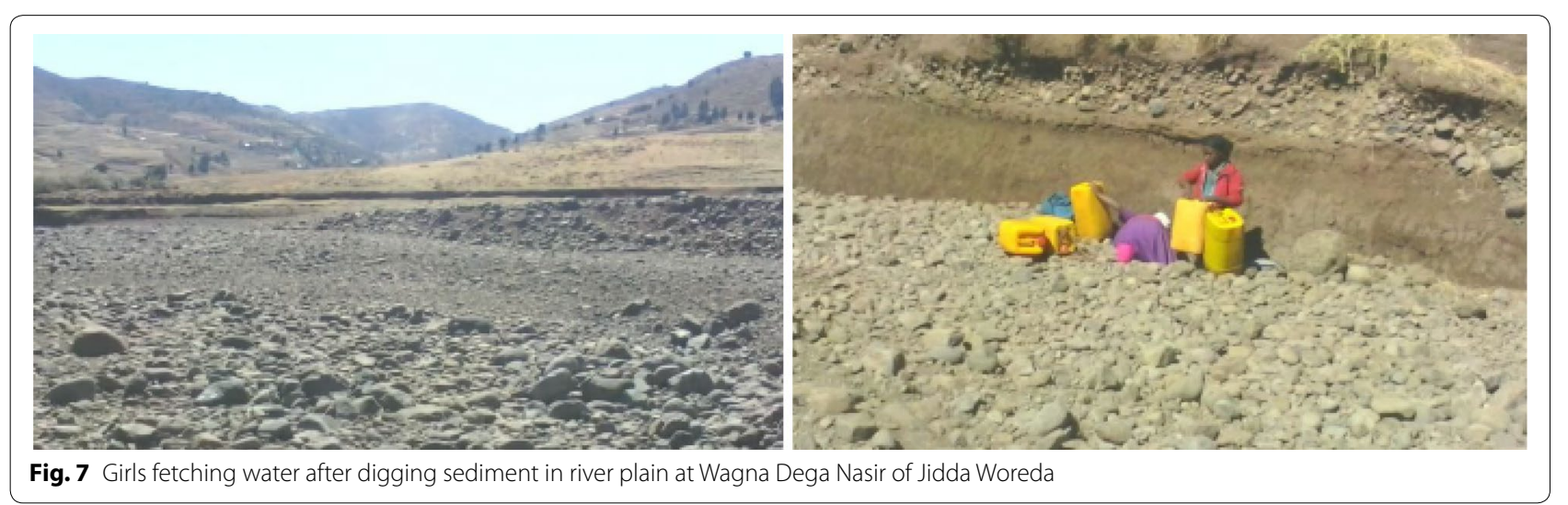

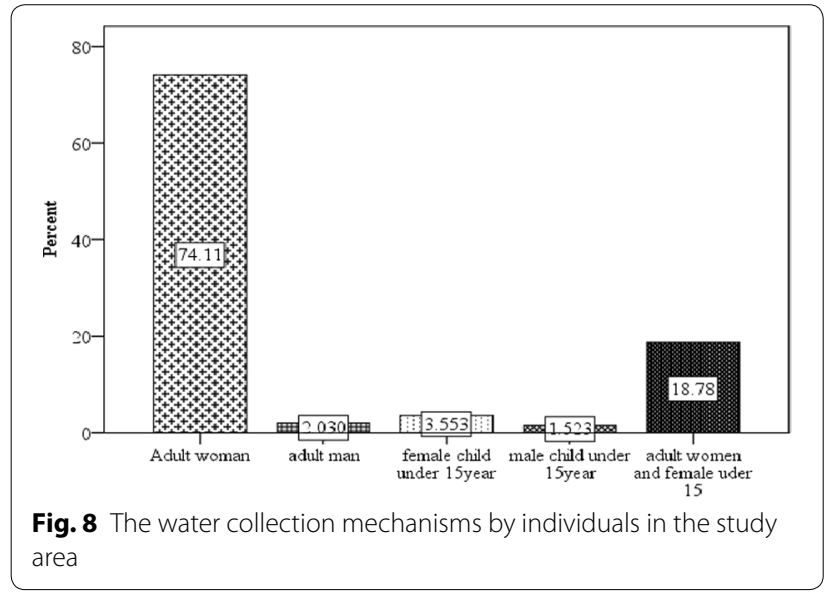

Kenya was more than $4 \mathrm{~h}$ per week, 4 to $6 \mathrm{~h}$ per week in Burkina Faso, Botswana and Cote D.Ivoire, and $17 \mathrm{~h}$ per week ( $2.43 \mathrm{~h}$ per day) for Senegal and $2.14 \mathrm{~h}$ per day in Mozambique during the dry season. The study of conducted in Zambia by Nkhuwa (2008) also show that, women and children face a major challenge of walking long distance of about 2-3 km per day, carrying heavy container between 20 and 25 litter per trip, long queues time and health risks from contaminated water.

The result from data analysis showed that average per capita of water per person within study area is about 14 litter. However, this was far lower than the threshold level of WHO standard which is 20 litter per day per person (WHO and UNICEF 2000).

The regression results of the comparison of the households' per capita water consumption within study area was as in Table 2 below. When there is an increase in household/family size, the probability of collecting more water for larger household size than smaller household. As a result, there is a positive relationship between household size and total water consumption. In this result, the per capita water consumption also show positive relationship and a unit increase of family size would lead to 0.017 times increase of per capita water demand and consumption because to fulfill the need of household the women increase the frequency of fetching. Accordingly, a unit increase in the frequency of water fetching were contribution for 3.86 time increase for the per capita water 
Table 2 Per capita household water consumption within study area

\begin{tabular}{|c|c|c|c|c|c|}
\hline \multirow[t]{2}{*}{ Model } & \multicolumn{2}{|c|}{ Unstandardized coefficients } & \multirow{2}{*}{$\begin{array}{l}\text { Standardized coefficients } \\
\text { Beta }\end{array}$} & \multirow[t]{2}{*}{$\mathrm{t}$} & \multirow[t]{2}{*}{ Sig. } \\
\hline & B & Std. error & & & \\
\hline (Constant) & 5.559 & 1.507 & & 3.688 & 0.000 \\
\hline Distance to be travelled to fetch & -0.590 & 0.284 & -0.115 & -2.078 & 0.039 \\
\hline Time spent to fetch water and come back & 0.107 & 0.366 & 0.016 & 0.294 & 0.769 \\
\hline Frequency of fetching per day ${ }^{\mathrm{a}}$ & 3.864 & 0.311 & 0.684 & 12.416 & 0.000 \\
\hline Average waiting/queuing time & 0.077 & 0.141 & 0.031 & 0.548 & 0.584 \\
\hline HH per capita income & -0.002 & 0.001 & -0.136 & -1.788 & 0.075 \\
\hline Family size & -0.017 & 0.117 & 0.011 & 0.143 & 0.887 \\
\hline
\end{tabular}

${ }^{a}$ Dependent variable: what is the per capita water demand for drinking per person?

consumption. There is negative relationship between distance travelled to fetch water and per capita water consumption and accordingly a unit $\mathrm{km}$ increase in distance will leads to a decrease of per capital consumption by 0.59 time since it is very harder to fetch water from very far distance on back. Similarly, unit increase of household per capita income would result in a decrease of per capita consumption by 0.002 times. This is because the demand for using water for different purpose would increase as the economic status of an individual household increases.

\section{Health impact}

Access to safe drinking water reduces the burden of infection disease outbreak and increases life expectancy (American Water Works Association 1953). However, due to low accessibility of drinking water within study area several types of water borne diseases were observed as in Table 4 below. According to the report of WHO (2004a, b) the lack of access to safe water and sanitation services has direct health impact. Furthermore, in the study area, the impact was significant due to low educational background and lack of training with regard to how to manage poor quality water before using them in the house. Based on this research finding, low educational background (73.10 \%) combined with less accessibility of water (14 litter per capita per day) contributed for outbreak of water borne disease within study area. This was in line with the finding of Degnet et al. (2010) and Getachew which states that low access to safe and adequate drinking water supplies were leading to communicable diseases and account three-fourth of health problems in Ethiopia. The Pearson Chi-square test showed that typhoid as the most common types of water borne disease in the study area (Table 3). Akeza and Taffere (2014) also confirmed that typhoid and giardia were the common water borne disease that occur due to poor quality water and lack of access to safe and improved
Table 3 Chi-square tests for water borne disease outbreak in the study area

\begin{tabular}{|c|c|c|c|c|}
\hline \multicolumn{2}{|c|}{ If yes what kinds of diseases? } & \multirow{2}{*}{$\begin{array}{l}\text { Value } \\
12.722^{b}\end{array}$} & \multirow{2}{*}{$\begin{array}{r}\mathbf{d f} \\
14\end{array}$} & \multirow{2}{*}{$\begin{array}{l}\begin{array}{l}\text { Asymp. sig } \\
\text { (2-sided) }\end{array} \\
0.548\end{array}$} \\
\hline Diarrhea & Pearson Chi-square & & & \\
\hline & Likelihood ratio & 13.334 & 14 & 0.500 \\
\hline & $\begin{array}{l}\text { Linear-by-linear } \\
\text { association }\end{array}$ & 0.708 & 1 & 0.400 \\
\hline & $\mathrm{N}$ of valid cases & 40 & & \\
\hline \multirow[t]{4}{*}{ Cholera } & Pearson Chi-square & $14.693^{c}$ & 12 & 0.259 \\
\hline & Likelihood ratio & 13.671 & 12 & 0.322 \\
\hline & $\begin{array}{l}\text { Linear-by-linear } \\
\text { association }\end{array}$ & 0.805 & 1 & 0.370 \\
\hline & $\mathrm{N}$ of valid cases & 34 & & \\
\hline \multirow[t]{4}{*}{ Typhoid } & Pearson Chi-square & $43.439^{d}$ & 18 & 0.001 \\
\hline & Likelihood ratio & 36.285 & 18 & 0.006 \\
\hline & $\begin{array}{l}\text { Linear-by-linear } \\
\text { association }\end{array}$ & 11.068 & 1 & 0.001 \\
\hline & $\mathrm{N}$ of valid cases & 47 & & \\
\hline \multirow[t]{4}{*}{ Giardia } & Pearson Chi-square & $7.969^{e}$ & 3 & 0.047 \\
\hline & Likelihood ratio & 4.834 & 3 & 0.184 \\
\hline & $\begin{array}{l}\text { Linear-by-linear } \\
\text { association }\end{array}$ & 0.067 & 1 & 0.796 \\
\hline & $\mathrm{N}$ of valid cases & 17 & & \\
\hline \multirow[t]{4}{*}{ Total } & Pearson Chi-square & $26.659^{a}$ & 27 & 0.482 \\
\hline & Likelihood ratio & 33.549 & 27 & 0.180 \\
\hline & $\begin{array}{l}\text { Linear-by-linear } \\
\text { association }\end{array}$ & 0.693 & 1 & 0.405 \\
\hline & $\mathrm{N}$ of valid cases & 141 & & \\
\hline
\end{tabular}

a 32 cells $(80.0 \%)$ have expected count less than 5 . The minimum expected count is .01

b 20 cells $(83.3 \%)$ have expected count less than 5 . The minimum expected count is .03

c 20 cells (95.2\%) have expected count less than 5. The minimum expected count is .12

d 25 cells ( $89.3 \%$ ) have expected count less than 5 . The minimum expected count is 02

e 7 cells ( $87.5 \%)$ have expected count less than 5 . The minimum expected count is .06 
water supply. The result from focus group discussion held with health expert of the each Woreda also explain that typhoid and giardia as the frequently occurring water borne disease. The finding agrees with the report of WHO (2004a, b) which states that $88 \%$ of diarrhea, typhoid, giardia and other water bone diseases were attributed to unsafe drinking water, safe water accessibility, inadequate sanitation and poor hygiene. Furthermore, out of 100 patient visiting hospital, above $85 \%$ of their diagnostic result shows that they are facing these disease as result of poor hygienic water.

Furthermore, fetching water using their own back and moving very long distance had different health problems. This is in line with the report of WSSCC (2006) which states that hauling heavy loads over long distances can lead to physical damage to the back and neck.

\section{Impact on education and agriculture}

The result of questionnaire survey indicated that poor water accessibility had greater impact on girls and women engagement in education. About $70.6 \%$ of the respondent reiterate the problem of water accessibility as hindrance factor for government objective towards education. In the study area, women and girls spent 3-4 h per day (i.e., 1095-1460 h per year) for fetching drinking water which is very higher than the $700 \mathrm{~h}$ spent per day per person in Ghana (WaterAid 2012). This implies that, on average one student will miss (absent) 37-51 day from the total effective learning period per year. As discussed earlier, $94.45 \%$ of the women were participating in water fetching within study area and hence they test the problem related to access to drinking water. Furthermore, the result of questionnaire of survey indicated that about $54.8 \%$ of their daughters were not enrolled for education. Fetching water $(45.2 \%)$, traditional barriers $(25.4 \%)$, school distance (11.2\%), illness (7.6\%), economic problem (5.6\%) and absence of schools (4.1\%) were the major possible reasons raised by respondent as given in Table 4.

The focus group discussion held with school teachers and result of data analysis showed that most of the girl students enrolled and following their education were facing a great challenge due to less access to drinking water. About of $77.4 \%$ of the female student in study area arrival to their school lately while $2.8 \%$ were arrive on time. However, $19.8 \%$ were completely absent from the school due to several reasons. The participation in class, quality of homework done and test score of most female students was poor which is about 58.5, 71.7 and $78.3 \%$ respectively (Table 5 ). This might be due to heavy load from fetching water and walking long distance to school.

According to WHO (2004a, b), basic access can be defined as the availability of drinking water at least $20 \mathrm{l}$
Table 4 The reason raised by respondent for not enrolling their daughters

\begin{tabular}{|c|c|c|c|c|}
\hline & Frequency & Percent & Valid percent & $\begin{array}{l}\text { Cumulative } \\
\text { percent }\end{array}$ \\
\hline Fetching water & 89 & 45.2 & 45.2 & 45.2 \\
\hline $\begin{array}{c}\text { Traditional } \\
\text { barriers }\end{array}$ & 50 & 25.4 & 25.4 & 70.6 \\
\hline Illness & 15 & 7.6 & 7.6 & 78.2 \\
\hline School distance & 22 & 11.2 & 11.2 & 89.4 \\
\hline $\begin{array}{c}\text { Absence of } \\
\text { school }\end{array}$ & 8 & 4.1 & 4.1 & 93.5 \\
\hline $\begin{array}{r}\text { Economic } \\
\text { problem }\end{array}$ & 11 & 5.6 & 5.6 & 99.1 \\
\hline Others & 2 & 1.0 & 1.0 & 100.0 \\
\hline Total & 197 & 100.0 & 100.0 & \\
\hline
\end{tabular}

per day per person, a distance of not more than $1 \mathrm{~km}$ from the source to the house and a maximum time taken to collect round trip of $30 \mathrm{~min}$. However, these are not the case in the study area. Therefore lack of access to drinking water were the major determinant factor for student participation in school and achievement of high quality education. This was in line with the finding of Cherutich et al. (2015) which states that the opportunity cost of water collection have social and economic dimensions. He further emphasized this point as, when the burden of collecting water fail disproportionally on females and children, it have cumulative effect on the education, health and safety of children including eroding their emotional wellbeing. One of the objective of Ethiopian millennium development goal was providing education for all community. However, this objective may not be achieved in areas where there is low access to drinking water.

The focus group discussion held with school teachers were also pinpointed that their schools also lack access to safe drinking water, sanitation and hygiene which in turn influence the education processes. Hence, not only access to drinking water to where the students live but also lack of safe drinking water in school compounds further influenced the teaching and learning activities. This was in line with (World Health Organization 2009) document which states that girls and boys are likely to be affected in different ways by inadequate water, sanitation and hygiene conditions in schools, and this may contribute to unequal learning opportunities. Sometimes, girls and female teachers are more affected than boys because the lack of sanitary facilities means that they cannot attend school during menstruation. Unequal participation of girl and females, which are half of population number, in achievement of millennium development goals, that target to eradication of extreme hunger and poverty; 
Table 5 Female student participation in school

\begin{tabular}{|c|c|c|c|c|c|}
\hline & Rate & Frequency & Percent & Valid percent & Cumulative percent \\
\hline \multicolumn{6}{|c|}{ a. How do you rate the lateness/arrival of your female students on coming to school? } \\
\hline \multirow[t]{4}{*}{ Arrival at school } & On time & 3 & 2.8 & 2.8 & 2.8 \\
\hline & Late-comer & 82 & 77.4 & 77.4 & 80.2 \\
\hline & Absent & 21 & 19.8 & 19.8 & 100.0 \\
\hline & Total & 106 & 100.0 & 100.0 & \\
\hline \multicolumn{6}{|c|}{ b. How would you rate class participation of your female students? } \\
\hline \multirow[t]{5}{*}{ Class participation } & Very poor & 21 & 19.8 & 19.8 & 19.8 \\
\hline & Poor & 62 & 58.5 & 58.5 & 78.3 \\
\hline & Good & 17 & 16.0 & 16.0 & 94.3 \\
\hline & Very good & 6 & 5.7 & 5.7 & 100.0 \\
\hline & Total & 106 & 100.0 & 100.0 & \\
\hline \multicolumn{6}{|c|}{ c. How would you rate the quality of homework of your female students? } \\
\hline \multirow[t]{6}{*}{ quality of homework } & Very poor & 22 & 20.8 & 20.8 & 20.8 \\
\hline & Poor & 76 & 71.7 & 71.7 & 92.5 \\
\hline & Good & 5 & 4.7 & 4.7 & 97.2 \\
\hline & Very good & 2 & 1.9 & 1.9 & 99.1 \\
\hline & Excellent & 1 & 0.9 & 0.9 & 100.0 \\
\hline & Total & 106 & 100.0 & 100.0 & \\
\hline \multicolumn{6}{|c|}{ d. How would you rate the quality of test scores of your female students? } \\
\hline \multirow[t]{6}{*}{ Quality of test score } & Very poor & 16 & 15.1 & 15.1 & 15.1 \\
\hline & Poor & 83 & 78.3 & 78.3 & 93.4 \\
\hline & Good & 2 & 1.9 & 1.9 & 95.3 \\
\hline & Very good & 3 & 2.8 & 2.8 & 98.1 \\
\hline & Excellent & 2 & 1.9 & 1.9 & 100.0 \\
\hline & Total & 106 & 100.0 & 100.0 & \\
\hline
\end{tabular}

and promoting gender equality and women's empowerment, may not be successful due to the above mentioned problem.

Extreme hunger and poverty eradication of millennium development goal of Ethiopia would be achieved if agricultural activity include females and girls, which account more than half of total population (CSA 2007). However, as discussed earlier under water accessibility section, most the females and girls spent $3-4 \mathrm{~h}$ per day by searching for drinking water which influence their participation in agriculture (Boxes 1,2). This was line with WHO (2004a, b) report stating 40 billion working hour spent for carrying water in Africa and sustainable agriculture is impossible unless sort of adjustment made with access to drinking water. The lack of water for livestock were also the major problem observed in the area. About $75 \%$ of the respondent explained the issue as they were trekking long distance for taking their livestock to water point. Furthermore, they walk long distance by holding water on their back and feel tried though they participate.

According to the 2004 United National General Assembly resolution 58/217, "water is critical for sustainable development, including environmental integrity and

\section{Box 2 .}

Mr. Galato Kumsa, one among the participant in focus group discussion said that "agriculture activity in our country requires huge amount of labor for achieving our desire and feeding our families but currently we are working with one hand due to unavailability of our women in agricultural activity. They are running here and there for looking water and almost all their time was spent on fetching water. During the earlier period it was the traditional barriers that hinder us not to participate our female in field work like provision of assistance for male in field work rather than restricting them in home. Awareness creation made by our government and extension worker help us to see our females and women as one wing for success of our agricultural activity and economic development. However, currently our great enemy and bottleneck in our kebele was lack of access to drinking water that prevent participation of our family members mainly girls and females in agriculture. This coupled with change in climatic condition were strongly hampering our economic income and livelihood activity".

the eradication of poverty and hunger, and is indispensable for human health and well-being" (UNESCO 2004). The finding of Ishaku (2011), Schultz (2001) and Yankey et al. (2011) also showed that water accessibility play a significant role in the achievement of socio-economic development of the community. Besides this, sustainable management of water resources is seen as vital for 
economic growth, public health, food security and stable societies (United Nations 2010). Access, availability and affordability to water and sanitation, is seen as essential for sustainable development and poverty eradication (Mwanza 2005). The finding of this particular research showed that the area was facing great pressure from water inaccessibility and lack of females participation since they spend much of their time for fetching water from very far distance.

\section{Conclusion and recommendation}

This report provides strong evidence that in Jidda and Wuchale Woreda, where the study was conducted, access to safe drinking water was the major strange though getting safe drinking water was one of the human rights. The main sources of drinking water was river followed by unprotected spring and pond which had great impact on human health due to common use of water point both for cattle, human being and other living things which makes it to have poor hygiene and sanitation. Beyond prevalence of water borne diseases, more time was spent for fetching this water which had cumulative impact on girl's and female's education, health and participation in other development activities. It is impossible to achieve millennium development goals which target to eradication of poverty, promoting gender equality and empowerment as well as combating diseases. Hence, urgent response should be given to the community with regard to provision of safe drinking water.

\section{Abbreviations \\ CSA: Central Statistics Agency; ETB: Ethiopian Birr; GDP: gross domestic prod- uct; GTP: gross and transformation plan; UNESCO: United Nations Educational, Scientific and Cultural Education; UN: United Nations; USD: United States Dollar; WHO: World Health Organization.}

\section{Authors' contributions}

GD carried the whole activities starting from generation of research idea, design of the study, data collection, data analysis, data interpretation, preparation of manuscript in a way it ready for publication); MB participated in data collection and data entry; BS take part in data collection, data entry, data interpretation and comment the layout of paper. All authors read and approved the final manuscript.

\section{Authors' information}

Getachew Demie - Lecturer at Hawassa University Wondo Genet College of Forestry and Natural Resources. He mainly teaches courses related to Environmental resource management, water pollution, land degradation and Rehabilitation. He published two papers in areas of soil contamination.

\section{Acknowledgements \\ Many people contributed to this study. Foremost, we would like to extend our gratitude to Wucale and Jidda Woreda employee for their time and insight. We are grateful contribution made by Research and development office of Wondo Genet College of Forestry and Natural Resources for providing finan- cial support to conduct this research.}

\section{Competing interests}

The authors declare that they have no competing interests.
Received: 13 November 2015 Accepted: 16 February 2016

Published online: 05 March 2016

\section{References}

Akeza A, Faffere A (2014) Water supply, sanitation and hygiene for health extension workers. A Short Term Training Manual of Ethiopian Institute of Water Resources. Addis Ababa University.

American Water Works Association (1953) Water quality and treatment. American Water Works Association Inc., New York p451

Amy JP, Jennifer D (2012) Freshwater availability and water fetching distance affect child health in sub-Saharan Africa. Environ Sci Technol 46(4):2391-2397

Begashaw G (2003) Community health, water supply and sanitation. Paper presented on Workshop held by Ministry of Water Resource/EARO/IWMI/ ILRI. Availabe at publications http://iwmi.org/pdf/H032453.pdf

Biswas KA (2004) Integrated water resources management: a reassessment a water forum contribution. Int Water Res Assoc 29(2):248-256

Cherutich J, Timothy M, Quinter O (2015) Water access and sustainable rural livelihoods: a case of elementaita Division in Nakuru County, Kenya. Int J Sci Technol Soc 3(1):9-23. doi:10.11648/j.ijsts.20150301.12

CSA (2007) Population and housing census of Ethiopia: results for Oromia Region, vol 1, Tables 2.1, 2.5, 3.4. Accessed 26 June 2013

De Albuquerque C (2012) Report of the special rapporteur on the human right to safe drinking water and sanitation; United Nations General Assembly: NY, USA. http://daccess-adds-ny.un.org/doc/UNDOC/GEN/N12/456/53/ PDF/N1245653.pdf?

Degnet A, Fanaye T, Tewodaj M (2010) Access to improved water source and satisfaction with services. Evidence from rural Ethiopia. International Food Policy Research Institute. IFPRI Discussion Paper 01044

Garcia L (1998) Strategy for integrated water resources management.env-125 sustainable development department, interamerican development bank. Washington, DC

Ishaku JM (2011) Assessment of groundwater quality index for Jimeta-yola area, Northeastern Nigeria. J Geol Min Res 3(9):219-231

Kerstin D, Cara F (2012) People, politics, the environment and rural water. http://www.who.int/water_sanitation_health/wsh0404/en/

Kidanemaraim J (2009) Water, sanitation and hygiene: sustainable development and multisectoral approaches. In: 34th WEDC international conference on participatory integrated water resource management (IWRM) planning: lessons from berki catchment, Ethiopia

Korca B, Jusufi K (2015) Awareness of kosovar stakeholders and citizens in the context of accessing safe drinkable water for all. IJSBAR 23(2):354-358

Luis SP, Ian C, lacovos I (2002) Coping with water scarcity. Int Hydrological Programme. IHP-VI Technical Documents in Hydrology No 58. UNESCO, Paris

McCommon C, Perez E, Rosensweig F (1998) Providing urban environmental services for the poor: lessons learned from three Pilot projects. EHP Applied Study No. 7. Environmental Health Project, Arlington, Virginia

Ministroy of Finance and Economic Development (2012). Assessing Progress Towards the Millinium Development Goals. Ethiopia Millinium Development Goals Report. Available at http://www.mofed.gov.et OR http:// www.et.one.un.org

Mwanza D (2005) Water for sustainable development in Africa. The World Summit on sustainable development. Springer, Dordrecht, pp 91-111

Nkhuwa DCW (2008) Water supply provision for poverty alleviation in rural areas of Zambia. In: Groundwater and Climate in Africa (Proceedings of the Kampala Conference, June 2008) IAHS Publ. 334, 2009. 9 December 2010

OAS (1998) Integrated Water Resources Management in Mesoamerica. In: Final Report of the Workshop on Assessment and Implementation of Water Resources and Coastal Areas Initiatives in the Region, Panama City, October 20-22, 1997. Unit of Sustainable Development and Environment General Secretariat of the Organisation of American States Washington, D.C

Roy JL, Crow B, Swallow B (2005) Getting access to adequate water: community organizing, women and social change in Western Kenya. International Workshop on African Water Laws: Plural Legislative Frameworks for Rural Water Managment in Africa. Johannesburg, South Africa 
Samra SCJ and Fawzi SCM (2011) The right to water in rural Punjab: assessing equitable access to water through the Punjab rural water supply and sanitation project. Health Human Rights 13(2):36-49

Schultz TP (2001) Women's role in the agricultural household: bargaining and human capital investment. Handbook of agricultural economics, vol 1, chapter 8

UNESCO (2012) International Decade for Action, "Water for Life", 2005-2015; UNESCO Resolution adopted by the General Assembly on the report of the Second Committee (A/58/485) 58/217; UNESCO: Paris, France, 2004. Available online at http://www.unesco.org/water/water_celebrations/ decades/water_for_life.pdf

United Nations (2010) United Nations Sustainable Management of Water Resources Vital to Achieving Anti-Poverty Goals Delegates Told as Genera Assembly High Level Dialogue Marks World Water Day; General Assembly GA/10925; United Nations: New York, NY, USA. Available online: http:// www.un.org/News/Press/docs/2010/ga10925.doc.htm

Van de Walle D, Gayatri K (2010) Access to water, womens's work and child outcomes. Policy Research Working Papers 5302. Available at http:// ecom.worldbank.org

WaterAid (2012) What the Global Report on Disability Means for the WASH Sector; Water Aid: London, UK. Available online: http://www.wateraid.org/documents/report_what_ the_global_report_on_disability_means_for_the_wash_sector_pdf World Bank (2015) Ethiopian economic overview. (www.tradingeconomics. com/ethiopia/gdp-per-capita)
World Health Organisation (2004a) Water, sanitation and hygiene links to health. Available at http://www.who.int/water_sanitation_health/factsfigures2005.pdf

World Health Organisation (2004b) Evaluation of the costs and benefits of water and sanitation improvement at the Global level. Available at http:// www.who.int/water_sanitation_health/wsh0404/en/

World Health Organization (2009) Water, sanitation and hygiene standards for schools in low-cost setting. In: Adams J, Bartrana J, Chartier Y, Sims J (eds), WHO press, Geneva 27

World Health Organization and UNICEF (2000) Global Water Supply and Sanitation Assessment Report. World Health Organization and United Nation Children's Fund. Geneva, Switzerland

World Health Orgnaization and UNICEF (2006) Meeting the millinium development goal driking water and sanitation target: the urban and rural challenges of the decades. http://www.wssinfo.org/fileadmin/user.../ resources/1198239354-JMP_06.pdf

WSSCC (2006) For her it's the big issue. Putting women at the centre of water supply, sanitation and hygiene. Evidence report. Available at: http://www. wash-cc.org and http://www.genderwater.org

Yankey RK, Akiti TT, Osae S, Fianko JR, Duncan AE, Amartey EO et al (2011) The hydrochemical characteristics of groundwater in the Tarkwa mining area. Ghana Res J Environ Earth Sci 3(5):600-607

Young GJ, Dooge JCl, Rodda JC (1994) Global water resources issues. Cambridge University Press, Cambridge

\section{Submit your manuscript to a SpringerOpen ${ }^{\odot}$ journal and benefit from:}

- Convenient online submission

- Rigorous peer review

- Immediate publication on acceptance

- Open access: articles freely available online

- High visibility within the field

- Retaining the copyright to your article

Submit your next manuscript at $>$ springeropen.com 